\title{
EFFECTS OF SELF REGULATORY LEARNING, PERSONAL GOAL SETTING AND PERCEPTIONS OF THE TEACHING PROFESSION ON LITERACY OF VOCATIONAL TEACHERS
}

\author{
Milla Anifatul Rosada, Setiadi Cahyono Putro, and Hari Putranto \\ Universitas Negeri Malang, Malang, Indonesia \\ E-mail: milla.anifatulr@gmail.com
}

\begin{abstract}
Literacy of the vocational teachers can certainly improve aspects of knowledge, skills and attitudes of a person thus the main competence of teachers can be achieved. The objective of this study was to reveal the relationship and the contribution of self regulatory learning $\left(\mathrm{X}_{1}\right)$, personal goal setting $\left(\mathrm{X}_{2}\right)$, and perception of the teaching profession $\left(\mathrm{X}_{3}\right)$ with the literacy of vocational teachers $(\mathrm{Y})$. This study used a quantitative method with descriptive correlational research design. The sample of this study consisted of the students of the bachelor degree program of Electrical Engineering Education in the Faculty of Engineering, Universitas Negeri Malang in the academic year of 2014 with 114 respondents. Data collection techniques used a questionnaire adapted using a likert scale. Data analysis used multiple linear regression analysis. The results showed there was a significant relationship between $\mathrm{X}_{1}, \mathrm{X}_{2}$, and $\mathrm{X}_{3}$ with $\mathrm{Y}$ either partially or simultaneously. The ability of self regulation learning, personal goal setting, and perceptions of the teaching profession contributed $56.3 \%$ to achieving literacy of vocational teachers, with a variable sequence that contributes from high to low were self regulatory learning, perceptions of the teaching profession and personal goal setting.
\end{abstract}

Keywords: literacy of vocational teacher, personal goal setting, perception of teaching profession, self regulatory learning,

\section{INTRODUCTION}

Vocational Education and Training (VET) has a major role in the economic development of developing countries, particularly in Indonesia. Although the government has used this system, VET in Indonesia still deals with many challenges and has low quality [1]. It is indicated by the fact that $50 \%$ of educators in Indonesia do not have the quality in accordance with National Education Standards [2].

Education Institute for Teaching Personnels or Lembaga Pendidikan Tenaga Kependidikan (LPTK) is a university that must organize teacher procurement programs, including teachers of Vocational High School or Sekolah Menengah Kejuruan (SMK) [3]. Universitas Negeri Malang (UM) is one of the LPTK that has the goal of organizing education, research and community service to prepare graduates who are smart, religious, noble, independent and able to develop professionally [4].
The bachelor degree program of Electrical Engineering Education is one of the teacher training programs under of the Department of Electrical Engineering Education, Faculty of Engineering UM. This program is designed to produce graduates expected to fill positions as electric and electronic clusters teachers in Vocational High Schools or instructors of training centers who have teachers and technical competencies [5]. The students of this program have significant influence on the next generation of vocational technology teachers. The ability of literacy is a complex understanding of information that is generated by the unity of language skills (reading and writing) connected by critical thinking [6]. In this case, literacy can certainly improve aspects of knowledge, skills, and attitudes of a person so that the primary competence of teachers can be achieved.

The culture of literacy in Indonesia is still categorized as very low. Sari [6] found out that literacy skills of early students of UM in 2015 about 55\%. It was announced in the World 
Most Literate Nations of the PIRLS and PISA 2016 that literacy in Indonesia was ranked $60^{\text {th }}$ out of 61 countries [7]. In addition, Supiandi [8] also explained that according to Anis Baswedan (2015) in an opportunity once revealed, one of the skills that must be owned by Indonesia Human Resources (HR) in the 21st century is literacy.

Supiandi [8] states that literacy or literacy ability is a person's ability not only defined as the ability to read and write. Similarly, Musfiroh \& Listyorini [9]state that literacy now has the meaning and implications of basic reading and writing skills to the acquisition and manipulation of knowledge. Kennedy et al. [10] suggest that literacy is considered important because it can develop reflection, criticism, and empathy. Besides, with literacy, someone will become more confident to be able to participate fully in community life. Saomah [11] explains that literacy is the making and interpretation of meaning through text with social, historical, and cultural practice. A grade of literacy is influenced by a series of cognitive abilities, knowledge of written and spoken languages, knowledge genre, and cultural knowledge.

Essentially teachers have a duty to educate, teach, guide, direct, evaluate and evaluate students [12]. Teachers have an important role in the education system to develop learning in learners [13]. Vocational technology teachers are required to have the main competencies described in Law no. Law No. 14 Year 2005 on Teachers and Lecturers covering pedagogic competence, personality competence, social competence and professional competence [4]. From various sources, it can be indicated that the literacy of vocational teacher is a person's ability to acquire and implement knowledge to become a competent vocational educator in his field.

The level of student literacy is unlikely to emerge from an individual. Kern [14] explains that to obtain high literacy requires a set of cognitive abilities in interpreting knowledge. Perceptions that can be interpreted as an individual's view of a person obtained from the sensing process will certainly affect the cognitive abilities that will increase the literacy of an individual.

Fitriani [15] explains that perception is the ability to organize an observation. Through the process of perception, humans will have the ability to classify and focus what is gained in the environment by its senses. According to Bandura's theory, perception becomes one of the factors that determine what individuals learn and how individuals act [16]. Mona [17] explaines that perception of the world of work becomes one of the things that affect students in determining his choice after graduation. The same thing also happens to students who have perceptions of work. In this case, the student should make his choice after graduating to become a vocational teacher in the electronics field.

The rapid development of information technology requires the position of teachers as professionals to develop professionalism so that they can still direct the students in facing the challenges of the development of the era [18]. Therefore, teachers also need to develop knowledge and skills in the profession. Some experts have stated that the perception of each person is certainly different according to the factors that influence it. The perception of students in the bachelor program of Electrical Engineering should be aware that they will be prepared to be prospective teachers. Students who do not have the perception of being prospective teachers, tend to be less interested in becoming a teacher. The impact is the tendency to ignore and deepen the teacher's courses. Through this course, students are formed to have the literacy to become a vocational teacher who has professional competence.

Based on the explanation, it can be indicated that the perception of students to the profession of teachers is a response or picture of students of work that requires a person to have expertise in the world of education as a teacher through the process of sensing. 
Setyowati [19] argues that a goal is an object or a purpose of behavior that has a standard and cultivated consciously. Arsanti [20] suggests the importance of goal setting described by some experts is as an improvement in performance so that an individual will generate higher achievement. This is in accordance with Lunenburg [21] who reveals that there is an important relationship between one's goals and performance. Effective performance can be generated when a person has a specific, challenging goal.

Goal setting defined by Setyowati [19] is a goal setting based on behavioral guidance for the achievement of perfection. This is in accordance with Zimmerman [22] who explains that a goal can improve the cognitive and affective ability of a person to the performance results because the goal determines the need for personal success. Determination of a goal is a process to think about a better future and can be a motivation for someone so that they can maximally realize what is expected in the future. This is relevant to the research of Wulan [23] which states setting individual goals increases the likelihood that the desired results will be achieved.

Primadewi [24] pointed out that the percentage of undergraduate students of the Department of Electrical Engineering Education, UM who have an interest in becoming teachers is $71.4 \%$. From the research data, it is known that there are students who have no interest to become teachers. Some students prefer other easier professions thus it can be expressed that they do not set the exact destination in accordance with the department. This gap later can affect the ability of students' literacy to become a competent vocational technology teacher.

Individuals who are committed to achieving their goals will also influence their upcoming actions through increased motivation. If someone sets a career goal well, then someone will seek knowledge and implement in the activity or can so have a high level of literacy.
From the above explanation, it can be said that personal goal setting is the determination of individual goals based on the direction of behavior to achieve something successfully. Setting one's goals strongly influences one's level of motivation to achieve something related to beliefs to engage in certain activities or to influence certain outcomes through thought and behavior. Determination of purpose, in this case, is in determining the individual goals in his career.

Friedmen \& Schustack [25] define selfregulation as a process whereby a person can manage their achievements and actions, set targets for themselves, evaluate their success as they reach the target, and reward themselves. Alwisol [26] explains that the Bandura Concept puts human beings as self-regulating persons, influencing behavior by regulating the environment, creating cognitive support, holding consequences for their behavior. In addition, Santrock [27] states that selfregulatory learning consists of self-awakening and self-monitoring of thoughts, feelings, and behaviors in order to achieve goals. Erdogan \& Senemoglu [28] explain that with selfregulation a person will control himself over his behavior. So if a person has high ability in selfregulating, then the person can easily achieve the expected target.

Kulum [29] concluded that self regulation could affect procrastination in inverse. Students who can manage their activities will be able to do the job well. Literation can not grow the same way. Literacy is derived from a range of cognitive, cultural, civic, and communication abilities. One must have self regulatory learning skills in order to be able to organize the way of learning appropriately to achieve the level of literacy to become a professional vocational technology teacher. These indicated that self regulatory learning is the ability of a person to organize himself in learning.

This study is important to reveal the connectedness of factors affecting the literacy of vocational teachers in a student of the 
Department of Electrical Engineering Education or prospectives teachers who can increase teachers' literacy. The students should also be able to prepare for a career to become a better vocational teacher in the future.

Based on the above description, the aims of this study are (1) to reveal the relationship and contribution of self regulatory learning $\left(\mathrm{X}_{1}\right)$, personal goal setting $\left(\mathrm{X}_{2}\right)$, and perception of teacher profession $\left(\mathrm{X}_{3}\right)$ with literacy of vocational teacher (Y) S1 PTE FT UM and (2) to reveal the relationship and contibution between $\mathrm{X}_{1}$ with $\mathrm{Y}, \mathrm{X}_{2}$ with $\mathrm{Y}, \mathrm{X}_{3}$ with $\mathrm{Y}$, and $\mathrm{X}_{1}, \mathrm{X}_{2}$, and $\mathrm{X}_{3}$ with $\mathrm{Y}$.

\section{METHOD}

This study used a quantitative method with a descriptive correlational research design to reveal whether there is a relationship between one variable with other variables either partially or simultaneously. The variables of this research are self regulatory learning $\left(\mathrm{X}_{1}\right)$, personal goal setting $\left(\mathrm{X}_{2}\right)$, and perception of teacher profession $\left(\mathrm{X}_{3}\right)$ as independent variable and literacy of vocational teachers $(\mathrm{Y})$ as the dependent variable.

The population in this study consisted of 124 students of the bachelor degree program of Electrical Engineering Education in the Faculty of Engineering, Universitas Negeri Malang in the academic year of 2014. Sampling technique in this study used purposive sampling. A suitable sample size determined with a Slovin formula with 5\% error rate was 95 students. The sample of this study were 114 respondents with the criteria of students active in the even semester of the academic year of 2017/2018, because of qualification criteria of Slovin formula as well as purposive sampling.

Data collection techniques used a questionnaire adapted using a likert scale. Questionnaire of each variable has fulfilled the requirement of validity and realibility. The questionnaire research variables $\mathrm{Y}, \mathrm{X}_{1}, \mathrm{X}_{2}$, and $\mathrm{X}_{3}$ obtained alpha values of $0.722,0.735,0.741$, and 0.723 respectively.

Based on the objectives of the study, the data analysis used was a descriptive analysis and a hypothesis testing using partial correlation analysis and a multiple regression analysis. Before testing the hypothesis, the prerequisite analysis in the form of tests: normality, linearity, multicollinearity, autocorrelation, and heteroskedasticity were conducted. After the data was stated to meet the prerequisite of the analysis, the hypothesis was tested tailored to the needs of research.

\section{RESULTS AND DISCUSSION}

The result of a prerequisite analysis test in this study can be seen in Table 1 and Figure 1. Normality test results indicated that the data were normally distributed. The linearity test results showed that the data had a linear relationship. Multicollinearity test results showed that the relationship between variables does not occur multicollinearity. The autocorrelation test results showed it did not autocorrelation. The result of heteroskedasticity test showed that it did not heteroskedasticity. The prerequisite test results of the analysis indicated that the results of this study met the prerequisite test analysis and could be examined with hypothesis testing. Hypothesis test results are partial in this study presented in Table 2.

Table 1. Table Results of the Prerequisite Analysis

\begin{tabular}{ll}
\hline \multicolumn{1}{c}{ Type of Tests } & \multicolumn{1}{c}{ Result } \\
\hline Normality & Psig X1 $=0.629$ \\
& Psig X2 $=0.581$ \\
& Psig X3 $=0.286$ \\
& Psig Y $=0.567$ \\
Linearity & Psig X1 $-\mathrm{Y}=0.000$ \\
& Psig X2 $-\mathrm{Y}=0.000$ \\
& Psig X3 - Y $=0.000$ \\
Multicollinearity & X1: T 0.739 VIP 1.354 \\
& X2: T 0.287 VIP 3.484 \\
Autocorrelation & X3: T 0.319 VIP 3.133 \\
& DW $=2.071$ \\
\hline
\end{tabular}




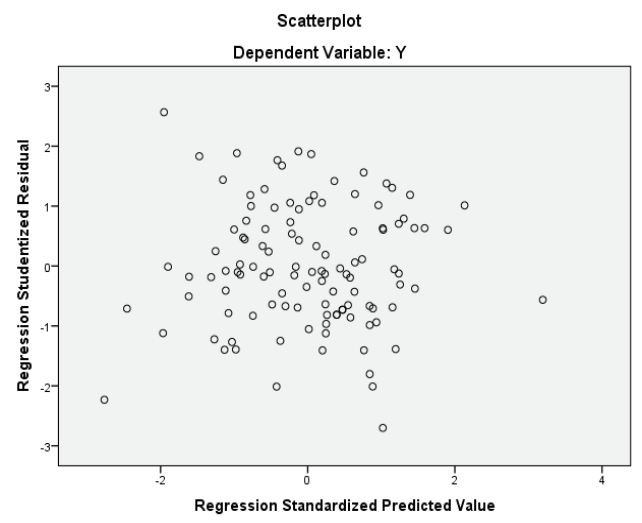

Figure 1. Test of Heteroskedasticity

Table 2. Results of Partial Correlation Analysis

\begin{tabular}{llll}
\hline \multirow{2}{*}{$\begin{array}{l}\text { Partial } \\
\text { Correlation }\end{array}$} & \multicolumn{2}{c}{ Probability } & \multirow{2}{*}{ Interpretation } \\
\cline { 2 - 3 } & $\mathrm{P}_{\text {sig }}$ & $\mathrm{P}_{\text {standar }}$ & \\
\hline $\mathrm{X}_{1}-\mathrm{Y}$ & 0.000 & 0.05 & Significant \\
\hline $\mathrm{X}_{2}-\mathrm{Y}$ & 0.040 & 0.05 & Significant \\
\hline $\mathrm{X}_{3}-\mathrm{Y}$ & 0.009 & 0.05 & Significant \\
\hline
\end{tabular}

Based on Table 2, $\mathrm{X}_{1}$ with $\mathrm{Y}$ has a positive and significant relationship. A person with a high level of self-regulatory learning ability will have the literacy of being a vocational teacher. If a person has a low level of self-regulatory learning ability, then the level of literacy to be a vocational technology teacher will also have a low effect.

Literacy to be a vocational technology teacher is a person's ability to acquire and implement knowledge to become a competent vocational educator in his field. The level of literacy to be a high-tech vocational teacher will have an impact on the readiness of graduates to become competent teachers. Kennedy et al. [10] describe that literacy is considered important because it can develop reflection, criticism, and empathy that will make a person more confident to be able to participate fully in the life of society.

Self-regulatory learning is one's ability to the self-organization in learning. According to Bandura in Alwisol [26] in the self-regulation will happen a reactive strategy used to achieve the goal, but when the goal is met there will be a proactive strategy to determine a new higher goal. A person who has high ability in self- regulating in achieving goals that refer to goal setting can increase the level of literacy, i.e., the individual has a cognitive ability about the sustainability of his activities in improving literacy skills into a competent vocational teacher.

It is known that $\mathrm{X}_{2}$ with $\mathrm{Y}$ has a positive and significant relationship. A person who has a high level of personal goal setting will make a person have the literacy to be a high vocational teacher as well. In this case, personal goal setting is more directed in the goal of becoming a vocational teacher. Sadowski \& Schranger [30] explain that the things involved in achieving career goals are to define individual career goals, measure current performance and plan to reorganize and prioritize performance according to career goals. In addition, Zimmerman [22] explains that goals can increase one's ability to performance outcomes.

Literacy has the meaning of acquisition and implementation of knowledge based on the right information. Ferianto [31] suggests that a career is a choice of profession or occupation that is the goal for an individual. The ability of a person to define a goal in work will affect how individual literacy is in determining what work activities are chosen appropriately. The career in question here is to become the vocational teacher of the main technology in the field of electro.

It is known that $\mathrm{X}_{3}$ with $\mathrm{Y}$ has a positive and significant relationship. A person who has a high level of student perception of the teaching profession will have the literacy of being a high-tech vocational teacher. If a person has a low level of student perceptions of the teaching profession, then the level of literacy being a vocational technology teacher will also have a low effect.

Santrock [32] defines perception as an interpretation of what someone has been cultivated. Perceptions of the teaching profession related to student interpretation can then perceive related to the teaching profession. Students who interpret the profession of teachers through the process of perception and 
the results of the process of perception will greatly affect the next activity.

. The actions of someone who refers to a career will surely have an impact on his literacy being a vocational teacher. A person will get a high literacy on a career based on what action performs through the process of obtaining the information as presented by Mona [17] and Bandura [16]. The results of the simultant analysis can be seen in Table 3 .

Table 3. Results of Simultant Analysis

\begin{tabular}{ccccccc}
\hline Sig. & \multicolumn{4}{c}{ Coefficient } & \multirow{2}{*}{$\mathrm{R}$} & $\begin{array}{c}\mathrm{R} \\
\mathrm{F}\end{array}$ \\
\cline { 2 - 5 } & Con. & $\mathrm{X}_{1}$ & $\mathrm{X}_{2}$ & $\mathrm{X}_{3}$ & & Square \\
\hline 0.000 & 3.764 & 0.493 & 0.296 & 0.289 & 0.563 & 0.750 \\
\hline
\end{tabular}

The relationship of $\mathrm{X}_{1}, \mathrm{X}_{2}, \mathrm{X}_{3}$ simultaneously with $\mathrm{Y}$ is positive and significant values obtained $\mathrm{r}=0.750$ ( $\mathrm{sig}=$ $0,000<0.05)$. It can be concluded that, the regression equation is $\mathrm{Y}=3.764+0.493 \mathrm{X}_{1}+$ $0.296 \mathrm{X}_{2}+0.289 \mathrm{X}_{3}$. The regression equation can be interpreted that the value of literacy to vocational teachers will be worth 3.764 when it is not influenced by the value of self-regulatory learning, personal goal setting, and perceptions of the teaching profession. Simultaneously between self-regulatory learning, personal goal setting and perception of teaching profession will influence the value of literacy to vocational teachers with a value of 0.493 added every 1 unit self regulatory learning increases, 0.296 of an increase every 1 unit personal goal setting and an increase value of 0.289 every increase of 1 unit of perception to teaching profession.

It is known that $\mathrm{X}_{1}, \mathrm{X}_{2}$, and $\mathrm{X}_{3}$ simultaneously have a positive and significant relationship. A person who has a level of selfregulatory learning, a personal goal setting level and a perception of a high profession of teachers will have the literacy of being a hightech vocational teacher. If a person has a level of self-regulatory learning, the level of personal goal setting and perceptions of the profession of the teacher, then the level of literacy becomes a vocational technology teacher will also have a low effect.
Literacy is the result of the acquisition and implementation of knowledge that can not be obtained easily. Kennedy et al. [10] explained that literacy is considered important because it can develop reflection, criticism, and empathy that will make a person more confident to be able to participate fully in the life of society. Therefore, in this case, it is required abilities to increase literacy to become vocational technology teachers.

Friedmen \& Schustack [25] state that self-regulatory is a process whereby a person regulates their achievements and actions. A better understanding of self-regulated learning will help a person to exercise control of their behavior, and it will have an impact on the increased success in teaching. The students of the Department of Electrical Engineering Education of UM have self-regulatory learning level categorized as high. The students can increase the conscious effort within himself in achieving the target.

Self-regulatory learning or self-regulated learning is one's ability to organize himself in learning. A person who has high ability in selfregulating in achieving goals that refer to goal setting can increase the level of literacy, i.e., the individual has a cognitive ability about the sustainability of his activities in improving literacy skills into a competent vocational teacher. Therefore, in this case, it is required the ability of self-regulatory learning to increase students' literacy to be vocational teachers.

Personal goal setting is a person's ability to set goals. Lunenburg [21] suggests that there is an important relationship between one's goals and performance. Effective performance can be generated when a person has a specific, challenging goal. The ability of a person to define a goal in work will affect how individual literacy is in determining what work activities are chosen appropriately. The career in question here is to become the vocational teacher of the main technology in the field of electrical engineering.

Fitriani [15] suggests that through perception, humans will have the ability to 
classify and focus what is obtained in the environment with the senses. Literacy has the meaning of acquisition and implementation of knowledge based on appropriate information. The ability of a person to define a goal in work will affect how individual literacy is in determining what work activities are chosen appropriately. As has been explained previously that the literacy that is the ability to read a person obtained through the process of sensing that involves the perception in obtaining it thus it can be linked that the perception of students on the teaching profession can affect the level of literacy to be a vocational technology teacher. The contribution of the predictor can be seen in Table 4.

Table 4. Contribution of Predictor

\begin{tabular}{ccc}
\hline Predictor & SR\% & SE\% \\
\hline $\mathrm{X}_{1}$ & $47.54 \%$ & $26.76 \%$ \\
$\mathrm{X}_{2}$ & $26.05 \%$ & $14.67 \%$ \\
$\mathrm{X}_{3}$ & $26.41 \%$ & $14.87 \%$ \\
Total & $100 \%$ & $56.3 \%$ \\
\hline
\end{tabular}

It is noted that simultaneously selfregulatory learning, personal goal setting and perceptions of the teaching profession have a relationship to the literacy of a vocational teacher. That is, combining the three capabilities of a person is in making selfregulation in learning, determining goals and have a perception of the profession of a high teacher or good to give simultaneous impact on the increase of students' literacy to be a vocational technology teacher. The effective contribution given by the three independent variables to the dependent variable is $56.3 \%$, where the effective contribution of $\mathrm{X}_{1}, \mathrm{X}_{2}$, and $\mathrm{X}_{3}$ is $26.76 \%, 14.67 \%$, and $14.87 \%$ respectively. This means self-regulatory learning, personal goal setting, and perceptions of the teaching profession contribute $56.3 \%$ to achieve literacy to be vocational teachers, with a sequence of variables that contribute from high to low is self-regulatory learning, the perception of the teaching profession and personal goal settings. The three independent variables give significant effect on the dependent variable, although
$43.7 \%$ can be influenced by other variables and factors which the researchers did not investigate.

\section{CONCLUSION}

This study suggests that a significant relationship between self-regulatory learning, personal goal setting and perceptions of the teaching profession with the literacy of vocational teachers either partially or simultaneously. The relative contribution of self-regulatory learning with literacy, personal goal setting with literacy and perceptions to the teaching profession with literacy to vocational teachers are $47.54 \%, 26.05 \%$, and $26.41 \%$ respectively. The effective contribution of selfregulatory learning, personal goal setting contribution, and perception of the teaching profession are $26.76 \%, 14.67 \%$, and $14.87 \%$ respectively. The ability of self-regulatory learning is a more effective predictor of literacy into vocational teachers. A student is expected to have the awareness to become a professional vocational teacher and to increase knowledge about self-regulatory learning, personal goal setting, perceptions of teacher profession, and literacy to be a vocational technology teacher and to prepare themselves to be a professional vocational teacher. It is expected that the next researcher will examine other aspects that influence the literacy of being a vocational technology teacher to contribute to improving teachers' competence.

\section{REFERENCES}

[1] T. Agrawal, "Vocational Education and Training Program (VET): An Asian Perspective," Asian - Pasific J. Coop. Educ., vol. 14, no. 1, pp. 15-26, 2013.

[2] T. Taniredja, P. Semedi, and M. Abduh, Guru yang Profesional. Bandung: Alfabeta, 2016.

[3] Ministry of National Education, The Law Number 14 Year 2005 regarding Teachers and Lecturers (Undangundang Nomor 14 Tahun 2005 tentang 
Guru dan Dosen). Ministry of National Education, 2005.

[4] U. N. Malang, Peraturan Rektor nomor 12 Tahun 2017 tentang Pedoman Pendidikan Universitas Negeri Malang. Universitas Negeri Malang, 2017.

[5] Universitas Negeri Malang, Kurikulum 2014 Jurusan Teknik Elektro Universitas Negeri Malang. Malang: Universitas Negeri Malang, 2014.

[6] M. I. Sari, "Pemetaan Kemampuan Literasi Mahasiswa Tingkat Awal Universitas Negeri Malang," Universitas Negeri Malang, 2016.

[7] Central Connecticut State University, "World's Most Literate Nations," 2017.

[8] Supiandi, "Menumbuhkan Budaya Literasi di Sekolah dengan Program Kata," in Simposium Guru Tahun 2016 Kementerian Pendidikan dan Kebudayaan Indonesia, 2016.

[9] T. Musfiroh and B. Listyorini, "No Title," J. Litera, vol. 15, no. 1, pp. 1-12, 2016.

[10] E. Kennedy, Literacy in Early Childhood and Primary Education (3-8 years. Dublin: National Council for Curriculum and Assessment, 2012.

[11] Saomah, "Implikasi Teori Belajar terhadap Pendidikan Literasi," J. Psikol. dan Bimbing., 2008.

[12] J. Suprihatiningrum, Guru Profesional: Pedoman Kinerja, Kualifikasi, \& Kompetensi Guru. yogyakarta: Ar-ruzz Media, 2013.

[13] S. Marfuah, I. W. Djatmiko, and M. Khairudin, "Learning Goals a Achievement of a Teacher in Professional Development," J. Pendidik. Teknol. dan Kejuru., vol. 23, no. 3, pp. 295-303, 2017.

[14] R. Kern, Literacy and Language Teaching. New York: Oxford University Press, 2000.

[15] Fitriani, "Studi Tentang Persepsi Guru Pendidikan Khusus Terhadap Buku Guru Dan Buku Siswa Dalam Kurikulum 2013 bagi Peserta Didik Berkebutuhan Khusus di SLB ABCD PGRI 2 JAJAG," J. Pendidik. Khusus, vol. 9, no. 2, pp. 1-11, 2017.

[16] S. C. Putro, H. Elmunsyah, H. Putranto, and A. M. Nidzom, "Pengaruh Aspek Sosial Psikologis terhadap Kesiapan
Menjadi Guru SMK di Jurusan TE FT UM," J. Teknol. dan Kejuru., vol. 40, no. 1, pp. 59-68, 2017.

[17] A. Mona, "Hubungan Persepsi terhadap Dunia Kerja dan Perilaku Praktikum dengan Kemandirian Menentukan Pilihan Setelah Lulus Sekolah pada Siswa Kelas XII Program Keahlian Teknik Elektro di SMK Negeri Kota Malang," Universitas Negeri Malang, 2016.

[18] R. Febriana, "Identifikasi Komponen Model Pelatihan Pedagogi Untuk Meningkatkan Profesionalitas Calon Guru Kejuruan," J. Pendidik. Teknol. dan Kejuru., vol. 23, no. 1, pp. 79-89, 2016.

[19] S. Setyowati, "Pengaruh Specific Goal Setting pada Perfomance," Universitas Sanata Dharma, 2016.

[20] T. A. Arsanti, "Hubungan Antara Penetapan Tujuan, Self-Efficacy dan Kinerja," J. Bisnis dan Ekon., vol. 16, no. 2, pp. 97-110, 2009.

[21] F. C. Lunenburg, "Goal Setting Theory of Motivation," Int. J. Manag. Business, Adm., vol. 15, no. 1, pp. 1-6, 2011.

[22] B. J. Zimmerman and A. Bandura, "Self Motivation for Academic Attainment: The Role of Self Efficacy Beliefs and Personal Goal Setting," Am. Educ. Res. J., vol. 29, no. 3, pp. 663-676, 1992.

[23] N. S. Wulan, "Hubungan antara Social Cognitive dan Penguasaan Keterampian dengan Kesiapan Memasuki Dunia Kerja bagi Siswa pada Kompetensi Keahlian TKJ SMK di Kota Malang," Universitas Negeri Malang, 2012.

[24] A. H. Primadewi, "Hubungan Keteladanan Dosen dan Persepsi Mahasiswa Terhadap Karir Keguruan dengan Minat Menjadi Guru pada Mahasiswa Program Studi S1 Pendidikan Teknik Elektro Fakultas Teknik Universitas Negeri Malang," Universitas Negeri Malang, 2016.

[25] H. S. Friedmen, Kepribadian Teori Klasik dan Riset Modern, Translated. Jakarta, 2008.

[26] Alwisol, Psikologi Kepribadian. Malang: UMM Press, 2010.

[27] J. W. Santrock, Life-Span Development Perkembangan Masa Hidup Ed. XIII Jilid I. Translated by Benedictine 
Widyasinta. Jakarta: Erlangga, 2012.

[28] Y. Erdogan and D. Dede, "Computer Assisted Project-Based Instruction: The Effects on Science Achievement, Computer Achievement And Portfolio Assessment," Int. J. Instr., vol. 8, no. 2, pp. 177-188, 2015.

[29] N. Kulum, "Hubungan Antara Self Regulation dan Self Efficacy dengan Prokrastinasi Penyelesaian Skripsi pada Mahasiswa Jurusan Diskimvis di Universitas Negeri Malang," Universitas Negeri Malang, 2012.

[30] E. Sadowski and S. Schrager," AchievingCareer Satisfaction: Personal
Goal Setting and Prioritizing for the Clinician Educator," J. Grad. Med. Educ., vol. 8, no. 4, pp. 494-497, 2016.

[31] A. Ferianto, "Penerapan Model Perkembangan Karir Ginzberg dengan Menggunakan Teknik Modeling untuk Meningkatkan Kesadaran Karir pada Siswa Kelas X TKR 3 SMK Negeri 3 Singaraja," E-jurnal Undiksa Jur. Bimbing. Konseling, vol. 2, no. 2, pp. 110, 2014.

[32] J. W. Santrock, Psikologi Pendidikan Ed 3. Translated by Diana Angelica. Jakarta: Salemba Humanika, 2009. 